\title{
Clinical and Clinico-Pathological Observations of Generalized Amyloidosis in Cattle
}

\author{
Tatsuo KONISHI, Shigeru ICHIJO and Sumio OGAWA \\ Department of Veterinary Medicine, Obihiro University of Agriculture \\ and Veterinary Medicine, Obihiro-shi, Hokkaido 080
}

(Received for publication November 20, 1974)

\begin{abstract}
Clinical and clinico-pathological observations were made on three cattle affected with generalized amyloidosis. The results obtained are as follows.

1. The main clinical symptoms of the three cattle were anorexia, continued watery diarrhea, edema of the subcutaneous tissue, and rapid emaciation. The clinical duration was 13 to 34 days. Prognosis was bad without any therapeutic effect in all the cattle.

2. The characteristic biochemical findings were advanced hypoproteinemia accompanied by hypoalbuminemia, hypobetaglobulinemia, hypogammaglobulinemia and hyperalphaglobulinemia. In the immunoelectrophoretic pattern of serum, precipitin lines were strong for alpha 1 lipoprotein and alpha 2 macroglobulin and mild for albumin and IgG.

3. Advanced renal proteinuria was shown by the urine which contained such protein components as albumin, alpha-, beta- and gammaglobulin. In the urinary sediment, there were renal epithelial cells, hyaline casts and leukocytes in all cases.

4. Severe amyloidosis was observed in all the affected cattle. Amyloid deposits were found in the wall of small blood vessels in almost all the organs, including the liver, spleen, pancreas, adrenal cortex, lymph nodes, alimentary tract and thyroid gland. The alimentary tract showed serious edematous changes in the submucosal tissue. In addition, there were multiple abscesses in the lungs (Case No. 1), chronic mastitis and suppurative peritonitis (Case No.2) and chronic mastitis (Case No.3).

5. No incidental causes of generalized amyloidosis were unknown in any case. It was suggested that the disease might follow the chronic infections described above.
\end{abstract}

It is a well-known fact that amyloidosis is observed in human being and many kinds of domestic animals and birds. Few papers, however, have been published to report natural cases in domestic animals. Particularly, the description of papers on amyloidosis in domestic animals in Japan is limited to pathological findings in cattle $[8,13]$, goats [8] and cats [9]. On bovine amyloidosis in other countries, Gilmann [2], Primgaard [11], Hjärre [4, 5], Cordy [1], Trautwein [14], Grunder et al. [3] and Murray et al. [7] reported pathological findings mainly, and few authors performed detailed clinical and clinico-pathological observations.

Recently, the authors obtained three cattle affected with generalized amyloidosis. In the present paper, the clinical and clinico-pathological findings of these cattle are chiefly described.

\section{Materials and Methods}

The cattle used for observation were Holsteins 9 to 12 years of age (Table 1). Initial clinical symptoms were found some time between 9 and 14 days after parturition. Prognosis was bad after a clinical duration of 13 to 34 days. Examination was made for clinical symptoms, hematological and biochemi-

牛に括忖る全身性アミロイド沈着症の臨休並びに臨㾁病理学的所見：小西辰雄・一条 茂・小川寿美雄（带広 䔔産大学家蓄内科学教穿) 
Table 1. Cattle examined

\begin{tabular}{cccccc}
$\begin{array}{c}\text { Animal } \\
\text { No. }\end{array}$ & Breed & $\begin{array}{c}\text { Age } \\
\text { (Years) }\end{array}$ & $\begin{array}{c}\text { Days } \\
\text { postpartum }\end{array}$ & $\begin{array}{c}\text { Clinical } \\
\text { duration (Days) }\end{array}$ & Termination \\
\hline 1 & Holstein & 9 & 19 & 24 & $\dagger$ \\
2 & Holstein & 12 & 50 & 34 & $\hbar$ \\
3 & Holstein & 11 & 140 & 13 & $\hbar$ \\
\hline
\end{tabular}

Fig. 1. Clinical findings of animal No. 1 affected with generalized amyloidosis

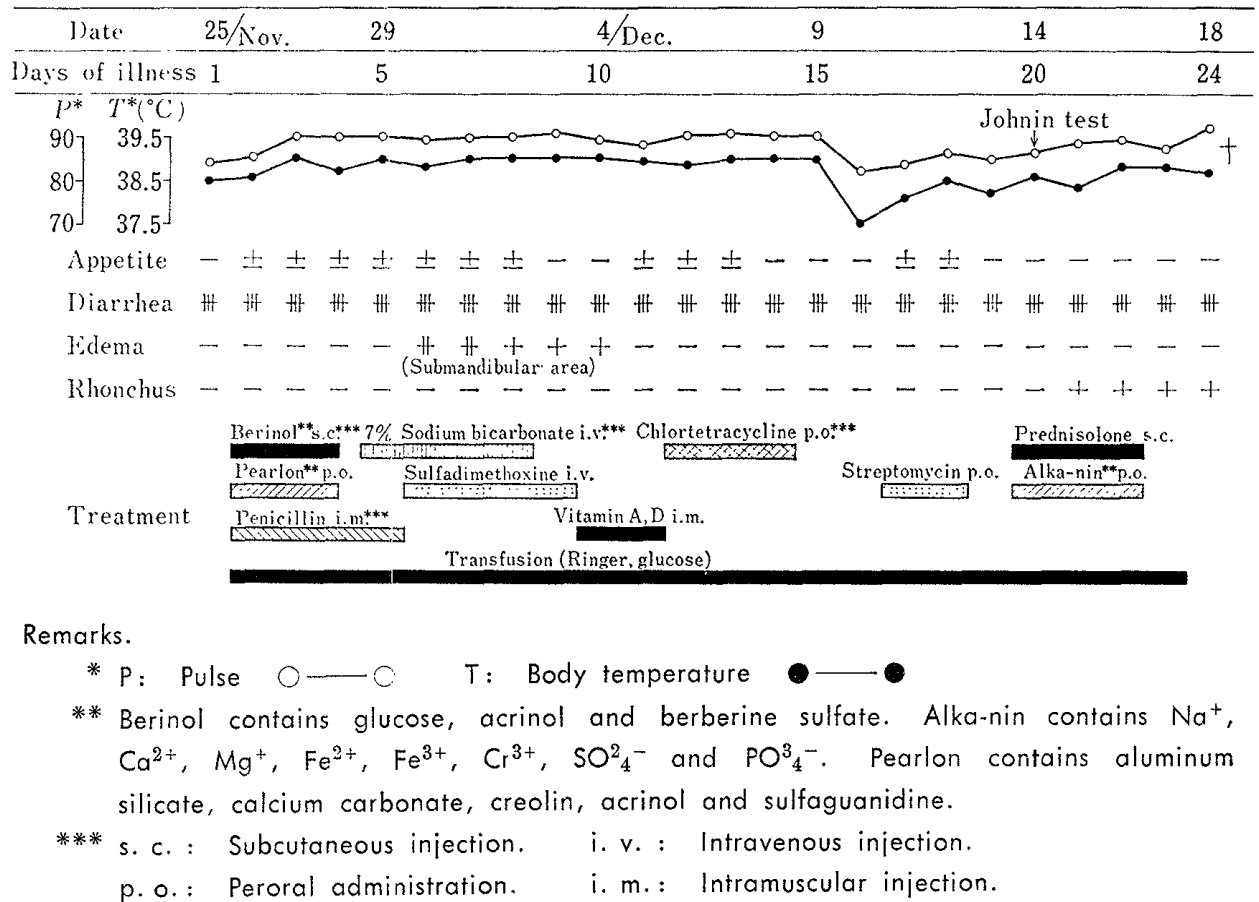

cal changes in blood and urine, and pathological findings.

\section{Results}

\section{Clinical findings}

Case No. 1: Initial clinical symptoms began with continued watery diarrhea of unknown cause appearing 19 days after parturition. Death occurred after a clinical duration of 24 days (Fig. 1). Feces had an offensive odor, accompanied by voluminous mucus, but contained no occult blood. In addition, the patient had no fever, but showed slight tachycardia of 8.5 to 90 per minute, dehydration and anorexia. She also had moderate edema of the submandibular area over a period from the 6 th to 10th days of disease and alveolar rale in the terminal stage. The Johnin test was performed in the caudal and cervical areas, but was negative in both areas. Various antidiarrheal drugs, including penicillin, streptomycin, oxytetracycline and sulfa drugs, and transfusion were used for treatment with little effect.

Case No. 2: After a clinical duration of 34 days, the patient found it difficult to rise. The initial symptoms manifested were anorexia, mucowatery diarrhea, and edema of the submandibular area. All of them were also observed in the terminal stage (Fig. 2). In addition, the patient showed pyrexia of $40^{\circ} \mathrm{C}$ on the 6 th and 8 th days and slight tachycardia during the pyretic and terminal 
Fig. 2. Clinical findings of animal No. 2 affected with generalized amyloidosis

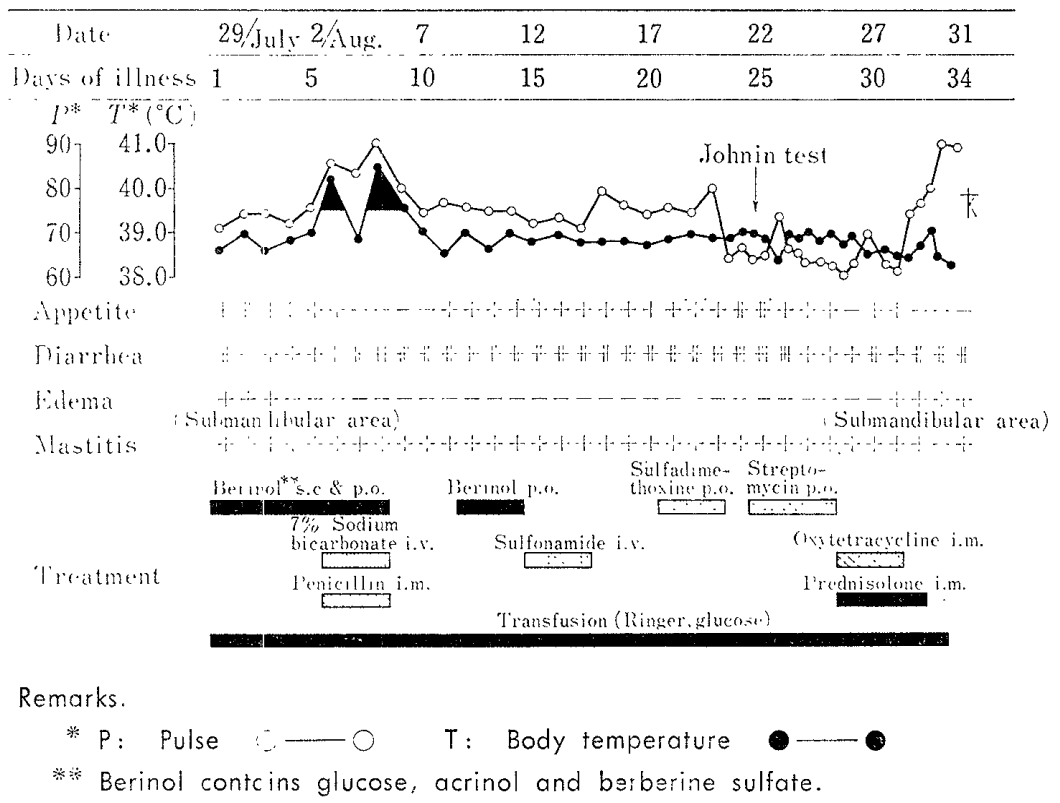

Fig. 3. Clinica findings of animal No. 3 affected with generalized amyloidosis

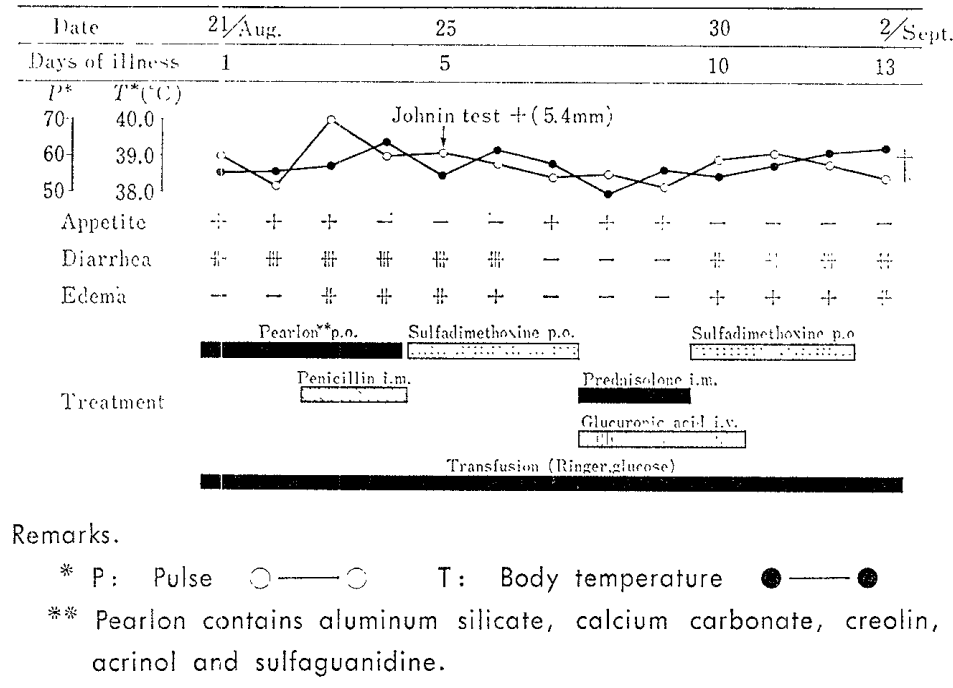

stage. The Johnin test was done only in the cervical area, where it was slightly positive with a swollen site $5.6 \mathrm{~mm}$ in diameter. Particularly, since parturition, she has been suffering from chronic mastitis of the bilateral anterior udders up to the present.

Various antidiarrheal drugs, including sulfa drugs, antibiotics, and adrenocortical hormone, and transfusion were used during the clinical duration with little effect.

Case No. 3: The patient could hardly rise after a clinical duration of 13 days (Fig. 3) and was killed for autopsy. She manifested no fever, but slight tachycardia, anorexia, dehydration and muco-watery diarrhea. Diarrhea continued throughout the clinical duration, except a period from the 7 th to 9 th days. Diarrheal feces con- 
Fig. 4. Hematological findings of three cattle affected with generalized amyloidosis

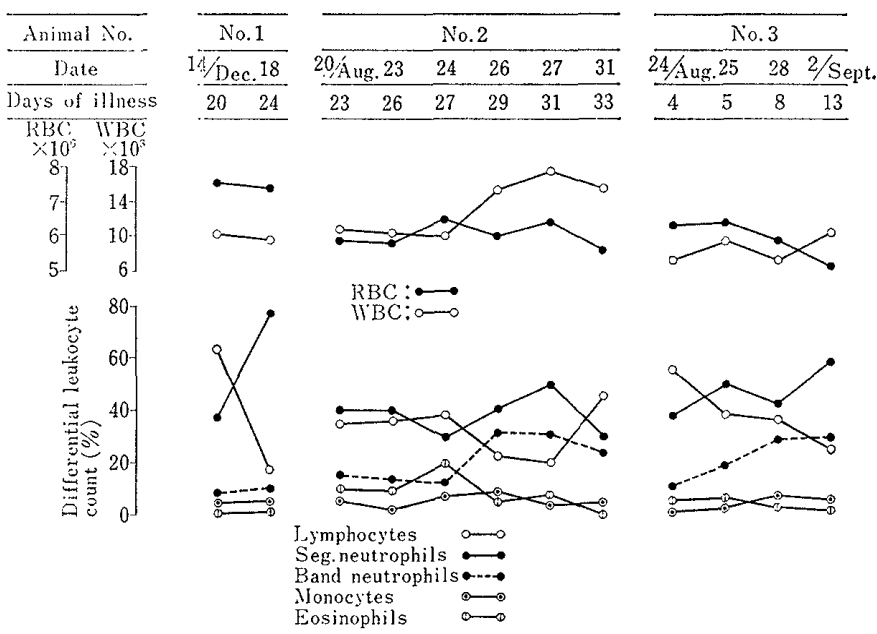

Fig. 5. Biochemical findings of blood of three cattle affected with generalized amyloidosis

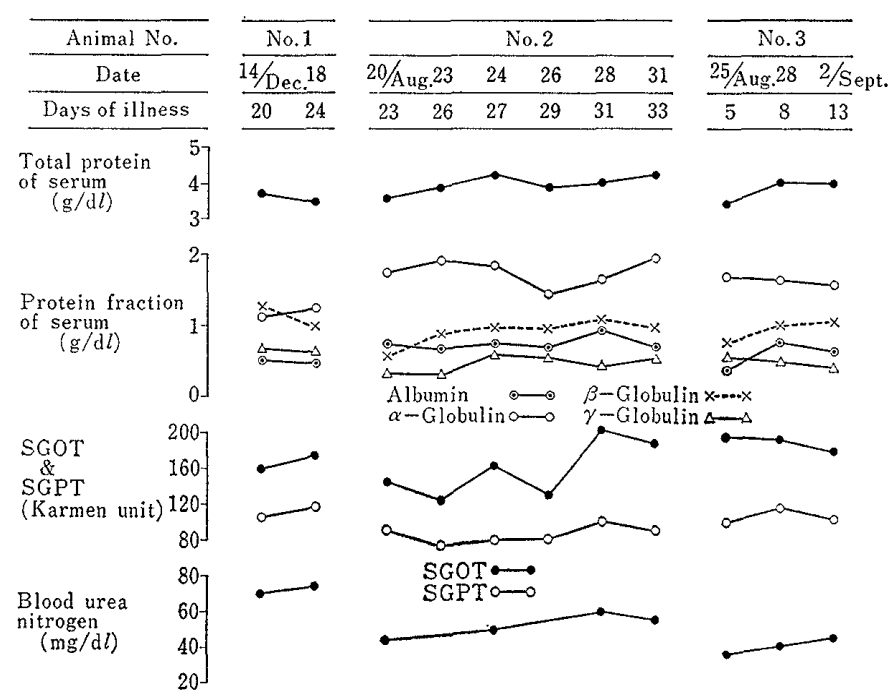

tained voluminous mucus, but had no occult blood. There was edema of the submandibular and anterior area of the chest. The Johnin test was carried out in the cervical area, showing a slightly positive reaction with a swollen site $5.6 \mathrm{~mm}$ in diameter. The same medication as in the former cases was applied with little effect. In addition, the patient had been suffering from chronic mastitis of the right anterior udder for about 4 years prior to treatment. She remained agalactic for a long time.

\section{Hematologic findings}

As shown in Fig. 4, hematological examination gave the following results.

a. Erythrocyte count: It ranged from 7.48 to 7.62 millions/cu. $\mathrm{mm}$ in Case No. 1 , from 5.54 to 5.84 millions/cu. $\mathrm{mm}$ in Case No. 2, and from 5.62 to 6.26 millions/cu. $\mathrm{mm}$ in Case No. 3. A slight decrease in erythrocyte count was observed in Cases No. 2 and No. 3.

b. Leukocyte count: It ranged from 9.4 to 10.0 thousand/cu. $\mathrm{mm}$ in Case No. 1 , 
Table 2. Urinary changes of three cattle affected with generalized amyloidosis

\begin{tabular}{|c|c|c|c|c|c|c|c|c|c|c|}
\hline \multirow[t]{2}{*}{ Animal No. } & \multicolumn{2}{|c|}{ No. 1} & \multicolumn{5}{|c|}{ No. 2} & \multicolumn{3}{|c|}{ No. 3} \\
\hline & $14 /$ Dec. & 18 & $20 /$ Aug. & 23 & 24 & 26 & 31 & $25 / A \cup g$. & 28 & 2/Sept. \\
\hline Days of illness & 20 & 24 & 23 & 26 & 27 & 29 & 33 & 5 & 8 & 13 \\
\hline $\mathrm{PH}$ & 7.3 & 6.6 & 6.8 & 6.4 & 6.2 & 6.0 & 7.0 & 6.0 & 6.0 & 5.8 \\
\hline Glucose & -- & - & - & - & - & - & - & - & - & - \\
\hline Urobilinogen & -- & - & - & - & - & - & - & - & - & - \\
\hline Acetone & $\therefore$ & + & - & - & - & - & - & - & - & - \\
\hline $\begin{array}{l}\text { Protein } \\
(\mathrm{g} / \mathrm{d} l)\end{array}$ & $\begin{array}{l}+t \\
(1.2)\end{array}$ & $\begin{array}{c}\text { H } \\
(1.5)\end{array}$ & $\begin{array}{c}\text { Ht } \\
(1.8)\end{array}$ & $\begin{array}{c}H \\
(2.0)\end{array}$ & HH & $\begin{array}{c}\text { Ht } \\
(2.65)\end{array}$ & H & $\begin{array}{l}+1 \\
(1.5)\end{array}$ & $\begin{array}{c}H \\
(2.0)\end{array}$ & $\begin{array}{c}\text { H } \\
(3.24)\end{array}$ \\
\hline Albumin & & & & & & 0.72 & & & & 0.97 \\
\hline$\sqsubseteq \subsetneq \equiv \alpha$-Globulin & & & & & & 0.90 & & & & 0.91 \\
\hline OS-Globulin & & & & & & 0.53 & & & & 1.06 \\
\hline$\gamma$-Globulin & & & & & & 0.50 & & & & 0.30 \\
\hline Epithelial cells of kidney & tt & $H$ & $H$ & $H$ & $H$ & $H$ & H & H & $H$ & H \\
\hline Hyaline cast & + & + & $+t$ & + & + & + & + & + & + & + \\
\hline Leukocyte & -- & + & H & H & $H$ & $\frac{11}{1+1}$ & $H$ & + & + & + \\
\hline
\end{tabular}

from 10.7 to 16.4 thousand/cu. $\mathrm{mm}$ in Case No. 2, and from 6.65 to 9.6 thousand/cu. $\mathrm{mm}$ in Case No. 3. Accordingly, marked leukocytosis was observed only in Case No. 2.

c. Differential leukocyte count: In all the cases, both segmented and band neutrophils increase markedly in number, while the lymphocyte count showed a decrease, and eosinophils decreased in number or disappeared in general.

\section{Biochemical findings}

Biochemical examination was conducted to clarify the concentration of total protein of serum, the activity of serum transaminase, and the concentration of blood urea nitrogen. The serum protein were examined by electrophoresis with cellulose acetate membrane and immunoelectrophoresis.

As shown in Figs. 5 to 7 , the following result were obtained.

a. Serum total protein: Marked hypoproteinemia was evident in all the cases examined. The concentration of serum total protein ranged from 3.6 to $3.7 \mathrm{~g} / 100 \mathrm{ml}$ in Case No. 1, from 3.6 to $4.2 \mathrm{~g} / 100 \mathrm{ml}$ in Case No. 2, and from 3.4 to $4.2 \mathrm{~g} / 100 \mathrm{ml}$ in
Case No. 3.

b. Electrophoretic pattern of serum protein: Common findings in the serum protein fraction were severe hypoalbuminemia $(0.5$ to $0.6 \mathrm{~g} / 100 \mathrm{ml}$ in Case No. $1,0.67$ to $0.94 \mathrm{~g} / 100 \mathrm{ml}$ in Case No. 2, and 0.43 to $0.79 \mathrm{~g} / 100 \mathrm{ml}$ in Case No. 3 for serum albumin), hypobetaglobulinemia (1.15 to 1.27 , 0.67 to 1.06 , and 0.79 to 1.09 for serum betaglobulin), hypogammaglobulinemia $(0.60$ to $0.65,0.35$ to 0.68 , and 0.48 to 0.62 for serum gammaglobulin), and hyperalphaglobulinemia (1.16 to $1.20,1.46$ to 1.94 , and 1.64 to 1.70 for serum alphaglobulin).

c. Immunoelectrophoretic pattern of serum protein: Immunoelectrophoresis was performed by the agar plate method in two cases, No. 2 and 3, and in one normal case. The immunoelectrophoretic patterns obtained are shown in Figs. 6 and 7. In them, albumin and IgG showed mild precipitin lines, and alpha 1 lipoprotein, alpha 2 macroglobulin, and betalipoprotein strong precipitin lines.

d. Serum transaminase: Serum glutamic oxalacetic transaminase (SCGOT) and serum glutamic pyruvic transaminase (SGPT) increased in activity in all the cases 
examined. The activity of SGOT ranged from 165 to 180 Karmen units in Case No. 1, from 134 to 202 in Case No. 2, and from 180 to 224 in Case No. 3.

The activity of SGPT ranged from 110 to 120 Karmen units in Case No. 1, from 76 to 104 in Case No. 2, and from 108 to 120 in Case No. 3.

e. Blood urea nitrogen: Blood urea nitrogen increased a little in concentration in all the cases examined. It ranged from 7 to $78 \mathrm{mg} / 100 \mathrm{ml}$ in Case No. 1, from 46 to 60 in Case No. 2, and from 40 to 48 in Case No. 3.

\section{Findings of urine examination}

The results obtained are shown in Table 2. Acidifying of $\mathrm{pH}$ was found in all the cases, that exhibited a range of $\mathrm{pH}$ from 5.8 to 7.3 .

Severe proteinuria was observed in all the cases. The Biuret method revealed a protein concentration ranging from 1.2 to $3.24 \mathrm{~g} / 100 \mathrm{ml}$. From the results of electrophoresis the protein fraction of urine was divided into four subfraction, albumin, alpha-, beta- and gammaglobulin. Microscopically, the urinary sediment consisted of renal epithelial cells, hyaline casts and leukocytes.

5. Bacteriological and serological findings In making a differential diagnosis on the affected cattle, attention was paid to bacteriological examination in order to determine whether these cattle were affected with Johne's disease or amyloidosis, since two of them (Nos. 2 and 3) had shown a positive reaction to the Johnin test. Attempts were made to detect Mycobacterium paratuberculosis from the feces and mucus of the rectum, but in vain. In addition, all the cattle exhibited a negative reaction to the complement fixation test for Johne's disease.

6. Pathological findings

The main autopsy findings of all the cases were as follows.

a. Enlargement in size of the kidneys, the cut surface of which showed cloudy changes and striated lesions with grayish white color.

b. Edema on the mucosal surface of the rumen, reticulum, abomasum and intestine.

The most marked lesions were observed in the kidney. Amyloid deposits were seen in the glomerulus (Fig. 8), capillary wall, and pericapillary parts of the renal medulla (Fig. 9). Many of the renal tubules in the medulla showed atrophy of epithelial cells and cystic dilatation of the lumen which was filled with hyaline casts. The amyloid substance found was stained brown by the iodine reaction and pink with Congo red, and was positive for the methylviolet or crystal violet metachromatic staining and PAS staining. Moreover, there were hyaline droplet degeneration of epithelial cells in the renal tubules (Fig. 10) and focal interstitial nephritis. In brief, the main lesion of the kidney was severe amyloid nephrosis. In only Case No. 1, abundant amyloid deposits were shown around the interlobular capillaries of the liver and accompanied by atrophy and disappearance of liver cells (Fig. 11). In the other two cases, liver changes were limited to amyloid deposits in the walls of small blood vessels in Glisson's sheath. Amyloid deposits were observed in the walls of small blood vessels in various organs, including the red pulp and lymph follicles of the spleen (Fig. 12), zona reticulata and zona fasciculata of the adrenal cortex (Fig. 13), interstitial tissue of the pancreas (Fig. 14), tunica propria of the digestive tract, lymph nodes, lungs, and perifollicular area of the thyroid glands. In addition, the digestive tract generally showed severe edematous changes in the submucosal tissue and mild catarrh lesions. There were multiple abscesses containing 
fungal masses in the lungs in Case No. 1, chronic mastitis of the anterior udders and suppurative peritonitis in Case No. 2, and chronic mastitis of the right anterior udder in Case No. 3.

\section{Discussion}

In Japan, only two cases of bovine amyloidosis have reported by Nakamatsu et al. [8] and Satoh et al. [13], respectively. They were examined mainly pathologically.

The present authors studied three bovine cases of generalized amyloidosis clinically and clinico-pathologically. In these cases, initial symptoms were anorexia, dehydration and muco-aqueous diarrhea. Marked edematous changes were also shown in the submandibular and anterior area of the chest.

Severe proteinuria was common to all the cases, the urine protein concentration exceeding $1.0 \mathrm{~g} / 100 \mathrm{~m} l$. The protein fractions were electrophoretically divided into albumin, alpha-, beta- and gammaglobulin. No detailed description has been made on the protein fraction, although the appearance of marked proteinuria has been reported in the cases of bovine amyloidosis by Hjärre [4], Grunder and Trautwein [3] and Murray et al. [7].

As other characteristic changes, severe hypoproteinemia with a decrease in albumin and gammaglobulin and an increase in alphaglobulin was exhibited by the affected cattle. From the immunoelectrophoretic pattern of serum protein, it was suggested that hyperalphaglobulinemia might have been induced by an increase in two fractions, alpha 1 lipoprotein and alpha 2 macroglobulin. The abovementioned findings made it clear that hypoproteinemia was caused by the flow of serum protein into the urine, resulting in functional damage of the kidneys. Particulorly, it was detected that the loss of serum protein from the kidneys was more marked in such low molecular fractions as albumin, transferrin and gammaglobulin than in such high molecular fractions as alpha 1 lipoprotein, alpha 2 macroglobulin and betalipoprotein.

These changes in serum protein and proteinuria should be included in the characteristic findings of nephrosis or amyloidnephorisis.

Detailed description is very scanty on the changes of serum protein in bovine amyloidosis. Rooney [12] pointed out alphaglobulin and Grunder et al. [3] an increase in alpha- and betaglobulin.

The results of the present study is considered to give a clinicopathological explanation for the relationship between severe hypoproteinemia and proteinuria in bovine amyloidosis which has not been clarified as yet. The present cases have been studied pathologically in detail by Ono et al. [10].

They presented amyloid deposits in almost all the generalized organs, including the kidneys, adrenal cortex, liver, spleen, lungs, digestive tract, lymph nodes and thyroid glands, in addition to marked edematous changes in the submucosal layer of the digestive tract.

Primgaard [11], Hjärre [4], Cordy [1], Rooney [12] and Satoh et al. [13] reported on cases with amyloid deposits in the kidneys, liver, spleen and adrenal cortex. Nakamatsu et al. [8] found cases with amyloid deposits in almost all the generalized organs. These findings were identical with the authors'.

In the present cases, amyloid deposits in the vascular wall of the alimentary tract were likely to induce acceleration of permeability for water and electrolytes and as a result, severe diarrhea and disorders of digestion and absorption. Moreover, amyloid deposits of the kidneys, namely, amy- 
loidonephrosis, seemed to be accompanied by severe renal proteinuria caused by the abundant flow of the low molecular components of serum protein. As a result of severe proteinuria induced by renal damage, serum albumin having a safe colloidal function to control osmotic pressure showed a significant decrease. Accordingly, severe hypoalbuminemia might have caused edematous changes in the digestive tract and subcutaneous tissue.

The pathological findings of amyloidosis have been classified in the following manners: (1) "lokale und atypische Amyloidose" by Weichmann (1893), (2) "typische und atypische Form" by Lubarsch [6], and (3) primary, secondary, and associated form with multiple myeloma by Reimann (1935). On the incidental causes of bovine amyloidosis, most of the previous workers recognized that almost all the causes might be secondary ones derived from chronic infections or chronic suppurative diseases, including Johne's disease, chronic traumatic reticulitis, chronic cystitis and abscesses of the lungs, liver and other organs.

All the present cases had chronic infections in common, such as multiple abscesses of the lungs in Case No. 1, chronic mastitis and suppurative peritonitis in Case No. 2, and chronic mastitis in Case No. 9. Accordingly, it is proposed that they should be classified into category of so-called secondary generalized amyloidosis.

Acknowledgments: Thanks are due to the Departments of Pathology and Microbiology, Obihiro University of Agriculture and Veterinary Medicine, for their advice.

\section{References}

[1] Cordy, D. R. (1949). Traumatic reticulitis, chronic nephritis, generalized edema and amyloidosis in a bull. North amer. Vet., 30, 504-508.

[2] Gilmann, H. L. (1920). Observation on amyloid degeneration in domesticated animals. $J$. Amer. vet. med. Ass., 57, 568-578.

[3] Grunder, H. H., and Trautwein, G. (1965). Das klinische und pathologische-anatomische Bild der Amyloidnephrose der Rindes. Deut. tierärztl. Wschr., 72, 442-447.

[4] Hjärre, A. (1933). Amyloid degeneration in animals. Acta path. microbiol., Scand., 16, 132-162.

[5] Hjärre, A. (1942). Über Amyloidose bei Tieren mit besonderer Berücksichtigung atypischer Formen. Berl. Münch. tierärztl. Wschr., 58, 331-334.

[6] Lubarsch, O. (1929). Zur Kenntnis ungewöhnlicher Amyloidablagerungen. Virchows Arch. Path. Anat., 27, 867-889.

[7] Murray, M., Rushton, A., and Selman, L. (1972). Bovine renal amyloidosis: A clinicopathological study. Vet. Rec., 90, 210-216.

[8] Nakamatsu, M., Fujimoto, Y., Satoh, H., Nakagawa, M., and Kagota, K. (1962). Amyloidosis in cows, sheep and goats occurred in a breeding farm. Jap. J. vet. Sci., 24, Suppl., 424-425 (in Japanese).

[9] Nakamatsu, M., Goto, M., and Morita, M. (1966). A case of generalized amyloidosis in the cat. Jap. J. vet. Sci., 28, 259-265.

[10] Ono, T., Sasaki, S., and Tamura, S. (1973). Generalized amyloidosis in cattle-A report of three cases. Res. Bull. Obihiro Univ., 7, 561576 (in Japanese).

[11] Primgaard, T. (1929). Amyloidnieren und Amyloiddegeneration beim Rind. Virchows Arch. Path. Anat., 274, 111-138.

[12] Rooney, J. R. (1956). Amyloidosis in a cow. Cornell Vet., 46, 369-378.

[13] Satoh, T., and Hirose, T. (1969). A case of bovine paratuberculosis. Jui Chikusan Shimpo, No. 492, 376-377 (in Japanese).

[14] Trautwein, G. (1965). Vergleichende Untersuchungen über Amyloid und Paramyloid verschiedenen Tierarten. I. Histomorphologie und färberische Eigenschaften des Amyloid und Paramyloid. Path. Vet., 2, 297-327. 


\section{Explanation of Figures}

Fig. 6. Immunoclectrophoretic patterns of serum protein in amyloidosis of cattle.

Fig. 7. Diagrammatic presentation of immunoelectrophoretic patterns of serum protein in amyloidosis of cattle.

Fig. 8. Kidney. Sercre amyloid deposit in the glomerulus. Hematoxylin and $\operatorname{cosin}$ (H-E) staining. $\times 840$.

Fig. 9. Medullary part of the kidney. Amyloid deposit in the interstitial tissue. H-E. $\times 840$.

Fig. 10. Medullary part of the kidney. Hyaline droplet degeneration of renal tubules. H-E.

Fig. 11. Liver. Severe amyloid deposit in sinusoidal space. Atrophy and disappearance of the hepatic cell cord. H-E. $\times 840$.

Fig. 12. Spleen. Amyloid deposit in the walls of small arteries in the red pulp. H-E. $\times 840$.

Fig. 13. Adrenal cortex. Amyloid deposit in perisinusoidal area in the zona reticulata. H-E. $\times 840$.

Fig. 14. Pancreas. Amyloid deposit in the interlobular connective tissue. H-E. $\times 840$. 


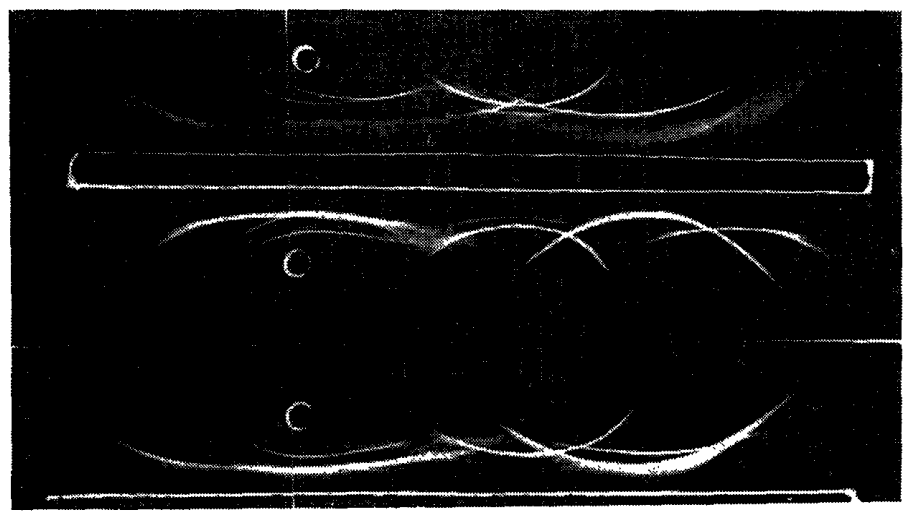

\section{Control}

Rabbit Anti-Bovine Serum

NO. 2

NO. 3

Rabbit Anti-Bovine Serum
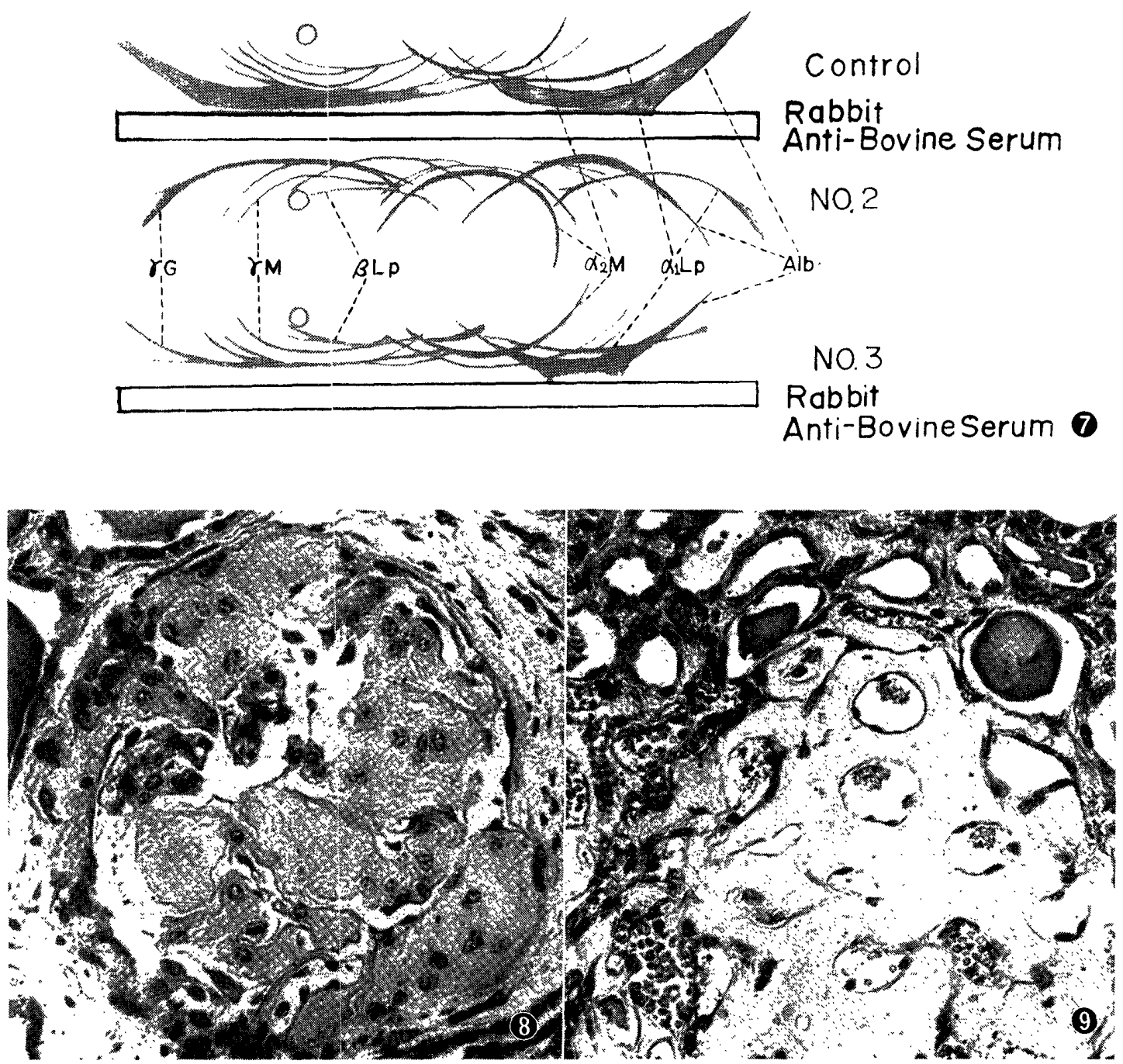

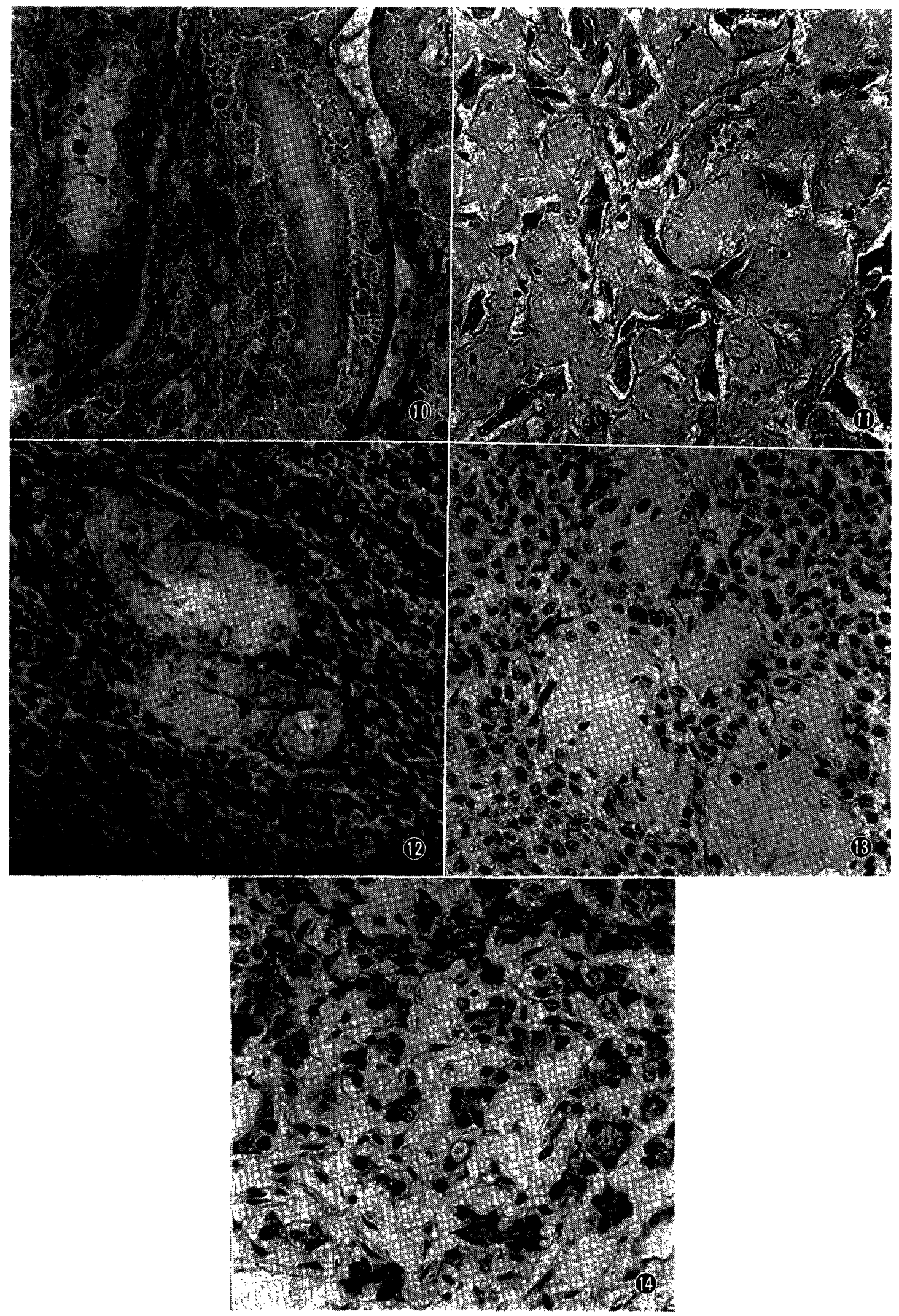